\title{
QUALITY OF SPECIALTY NATURAL COFFEE STORED IN DIFFERENT PACKAGES IN BRAZIL AND ABROAD
}

\author{
Flavio Meira Borém¹, Fabrício Teixeira Andrade², Cláudia Mendes dos Santos \\ Ana Paula de Carvalho Alves ${ }^{4}$, Gabriel Carvalho Matias ${ }^{5}$, Daniela Edel Teixeira ${ }^{6}$, \\ Paulo César Ossani 7 , Marcelo Ângelo Cirillo ${ }^{8}$
}

(Received: September 11, 2019; accepted: October 31, 2019)

\begin{abstract}
A challenge in the packaging and export of specialty coffees is to avoid green coffee bean storage and transport conditions that negatively affect the sensory quality of the roasted beans. The present study evaluated green beans of specialty coffees in eight types of packaging stored in a warehouse in the municipality of Poços de Caldas, Minas Gerais State, Brazil, for 18 months (Brazilian phase). This coffees were also subjected to sea transport and subsequent storage at a specialty coffee import company (export phase) in the United States, where it remained stored for 14 months. Physical, chemical, and sensory analyses of the beans were performed in the Brazilian phase and export phase. Green coffee beans stored in high-barrier packages had the best conserved quality. Packages with little or no barrier were not adequate for packaging or exporting specialty coffees. Beans in high-barrier packaging maintained their quality for long periods, which are therefore recommended for specialty coffee storage and export.
\end{abstract}

Index terms: Coffea arabica L., storage, export, sugar, deterioration.

\section{INTRODUCTION}

Quality is an important factor for coffee due to new consumer market demands, which increasingly involve coffee sensory characteristics. This demand can be seen in the expansion of specialty coffee market, which grows approximately $15 \%$ a year in Brazil, whereas the traditional coffee market grows approximately $2 \%$ a year. In addition, specialty coffee can be sold for much higher prices than commodity ones (Associação Brasileira de Cafés Especiais BSCA, 2017).

Shipping coffee beans is an usual operation in the global specialty coffee market. Most producing countries are located in tropical regions and export their coffee beans mainly to the northern hemisphere, where the largest coffee consuming countries are located. During shipping, coffee beans are exposed to long periods of time under extreme environmental conditions that can negatively change their color, taste and aroma. The hermetic bag is supposed to be able to avoid the negative effects of high temperature and relative humidity on the quality of coffee beans for longterm storage, both in its origin and transport to the final international destination.

Higher water content in dry-processed coffee makes the natural coffee more susceptible to undesirable fermentation when compared to the wet-processed ones. The higher water content in the fruit also exposes it to a longer drying period, which may lead to the loss of cell membrane integrity (ALVES et al., 2017; TAVEIRA et al., 2012), what often reflects reducing the initial sensory quality. This sensitivity is also observed during storage; the quality of natural coffee declines more quickly than pulped coffee under storage conditions (SAATH et al., 2012; RENDON, SALVA; BRAGAGNOLO, 2014).

As natural processing produces a more sensitive coffee, Brazil has a competitive advantage in producing it in relation to the to other producer countries. The development of new technologies for packaging green beans of natural specialty coffees is justified to extend the storage period without compromising the final quality. Thus, studying the temporal effects during this period is fundamental to improve recommendations for new packages and storage procedures.

The validation of results, which allowed us to recommend the packages evaluated in this work, was conducted by considering generalized estimating equation models (LIANG; ZEGER, 1986). We can incorporate a correlation structure to add information to the models, related to the strong correlation between close experimental units, such that, when the storage period gradually increases, this correlation tends to decrease. In this sense, the aim of the present study was to evaluate the behavior of natural beans of specialty coffee kept in different types of packaging in two phases

\footnotetext{
1,2,3,4,5,6 Universidade Federal de Lavras/UFLA - Departamento de Engenharia Agrícola/DEG - Cx. P. 3037 - $37.200-000$ Lavras - MG - flavioborem@ufla.br, fabriciotandrade@gmail.com, claumsantos@yahoo.com.br, anapaula.quimica@hotmail.com, gabrielcarvim@hotmail.com, danielaedel12@yahoo.com

${ }^{7,8}$ Universidade Federal de Lavras/UFLA - Departamento de Estatística/DES - Cx. P. 3037 - 37.200-000 - Lavras - MG ossanipc@hotmail.com,macufla@gmail.com
} 
of the experiment: first, storage in Brazil and, second, subjected to sea transport and subsequent storage at a specialty coffee import company in the United States.

\section{MATERIALS AND METHODS}

A commercial lot of natural specialty coffee containing approximately 40 bags of $60 \mathrm{~kg}$ was used. The coffee lot was homogenized in a holding bin and then divided into homogeneous fractions of $10 \mathrm{~kg}$. Green coffee beans fractions were placed in eight types of packages, with three replicates. The code and the description of the packages used are shown in Table 1.

The Paper packaging $(\mathrm{P})$ is composed by a double layer of kraft paper. Low barrier package (LB) is composed externally by a double kraft paper layer and internally by an oxygen permeable plastic film. The high barrier package (HPB) is externally composed by a double kraft paper and internally by an oxygen impermeable plastic film. The HB package consists of a single plastic film composed by 6 to 7 layers impermeable to oxygen. The antifog (AF) package is similar to HPB, but with an extra inner layer with the wet-absorbing property that eventually can be formed internally in the package.

The packages were characterized regarding Oxygen transmission rates (OTR) and Water vapor transmission rates (WVTR). OTR was determined according to the ASTM D398505 (2005) standard on an OXTRAN device $(\mathrm{MOCON})$. Water vapor transmission rates were determined on a PERMATRAN infrared sensor device (Model W3/31, MOCON) according to the procedure described in the ASTM F1249 13 (2013) standard. In the paper, + high barrier + antifog $+\mathrm{CO}_{2}(\mathrm{CO})$ treatment, carbon dioxide gas was injected until it reached a concentration of $10 \%$ inside the package. In the vacuum packing treatment (V), a TecMaq-300 machine was used (Table 1).

After packaging, all bags were distributed at random into two stacks arranged in a warehouse located in the municipality of Poços de Caldas, Minas Gerais State, Brazil. One of the stacks was used for the coffee storage phase in Brazil. Samples were collected at 0, 3, 6, 9, 12 and 18 months after coffee packaging in three replicates of each package type. The other stack was used for the export phase. This phase consisted in three months of storage in Brazil, one month of shipping and 10 months of storage in a warehouse in the municipality of Minneapolis, USA. Samples were collected at 0, 3, 6 and 14 months. Samples collected at 0 and 3 months were taken while the coffee was in the warehouse in Brazil, while samples collected at 6 and 14 months were taken at the warehouse in USA.

For the Brazil phase, a completely randomized experimental design (CRD) was used in an $8 \times 6$ factorial arrangement, corresponding to eight types of packages and six storage times $(0,3$, $6,9,12$, and 18 months), with three replicates. For the export phase, an $8 \times 4$ factorial arrangement was used, corresponding to eight types of packages and four storage times $(0,3,6$, and 14$)$, with three replicates. The temperature and relative humidity of the storage environment were recorded through sensors (thermohygrographs) attached out of the packages. The $\mathrm{CO}_{2}$ concentration inside the packages was measured at the time of sample collection using a gas analyzer (UEI brand, model $\mathrm{C} 20$ ). The results were expressed as $\mathrm{CO}_{2}$ percentage. The water content of green coffee beans was determined by the laboratory oven drying method, at $105 \pm 1{ }^{\circ} \mathrm{C}$ for $16 \pm 0.5$ $\mathrm{h}$ according to the standard method of ISO 6673 (International Organization for Standardization ISO, 2003).

A sensory analysis was performed by judges certified by the Specialty Coffee Association (SCA) using the SCA protocol according to the methodology proposed by Lingle (2011) for sensory evaluation of specialty coffees. The final results of the sensory evaluation were determined by the sum of all the attributes. In order to normalize the sensory analysis at all times of storage by creating a real reference to the initial coffee quality standard, roasted samples were collected at the initial storage time, placed in Falcon tubes and stored in a freezer $\left(-80^{\circ} \mathrm{C}\right)$. These samples were cupped in the following evaluations and used as calibration references so that the cuppers could refer back to the sensory experience from the initial storage period.

An analysis of sugars was performed according to the methodology proposed by Ribeiro et al. (2016). Sugar concentrations were determined using a liquid chromatograph (Shimadzu). The mobile phase was $20 \mathrm{mM} \mathrm{NaOH}$ at $35^{\circ} \mathrm{C}$ and a flow of $0.2 \mathrm{mLmin}^{-1}$. The injection volume of the samples was $20 \mu \mathrm{L}$, and a Carbopac PA1 ion exchange column was used. The results were defined by the ratio between the peak area of sugars in the sample and the respective known standard concentration. The final sugar concentration was expressed as percentage of dry matter (g.100 $\left.\mathrm{g}^{-1}\right)$. 
TABLE 1 - Code and description of the packages used.

\begin{tabular}{|c|c|c|c|}
\hline Code & Package description & $\begin{array}{l}\text { WVTR* }\left(\mathrm{g} \mathrm{m}^{-2} \text { day }^{-1}\right) \\
\left(37.8^{\circ} \mathrm{C} / 90 \% \mathrm{RH}^{* *}\right)\end{array}$ & $\begin{array}{c}\text { OTR* }^{*}\left(\mathrm{cc} \mathrm{m}^{-2} \text { day }^{-1}\right) \\
\left(23^{\circ} \mathrm{C} / \mathbf{0} \% \mathrm{RH}^{* *}\right)\end{array}$ \\
\hline $\mathrm{P}$ & Paper & - & - \\
\hline LB & Paper + low barrier & - & - \\
\hline HBP & Paper + high barrier & $<5$ & $<10$ \\
\hline $\mathrm{CO}$ & $\begin{array}{l}\text { Paper }+ \text { high barrier }+ \text { antifog }+ \\
\mathrm{CO}_{2}\end{array}$ & $<5$ & $<10$ \\
\hline HB & High barrier plastic & $<5$ & $<10$ \\
\hline $\mathrm{AF}$ & Paper + high barrier + antifog & $<5$ & $<10$ \\
\hline V & Vacuum & $<5$ & $<10$ \\
\hline $\mathrm{J}$ & Jute & - & - \\
\hline
\end{tabular}

* WVTR $=$ Water vapor transmission rates; OTR $=$ Oxygen transmission rates.

** $\mathrm{RH}=$ Relative humidity.

The method of estimating generalized equations proposed by Liang and Zeger (1986) was used to test the hypothesis that packages have an effect related to temporal dependence observed by repeated measures over time. In this context, the ratio between the mean of the response variables and the mean of the explanatory variables (factors and their interactions) was described by a linear predictor using the interactive data analysis $\mathrm{g}\left(\mu_{\mathrm{i}}\right)$, given by identity, as shown in expression (1).

$$
\mathrm{g}\left(\mu_{\mathrm{i}}\right)=X_{\mathrm{i}}^{\mathrm{t}} \beta ; \mathrm{i}=1, \ldots, \mathrm{n},
$$

where $\mathrm{n}$ is the total number of packages, $\mathrm{Xi}$ is the factorial design assumed for the $\mathrm{i}$-th package, and $\beta$ is the vector of parameters to be estimated. Given these specifications, the parameter estimates were obtained by solving the system defined by:

$$
\begin{aligned}
& \mathrm{U}_{\mathrm{k}}(\beta)=\sum_{\mathrm{i}=1}^{\mathrm{n}} \mathrm{D}_{\mathrm{i}} \mathrm{V}_{\mathrm{i}}^{-1} \mathrm{~S}_{\mathrm{i}}=0 \\
& \mathrm{D}_{i}=\frac{\partial \mu_{\mathrm{i}}}{\partial \beta_{\mathrm{k}}} ; \mathrm{S}_{\mathrm{i}}=\mathrm{y}_{\mathrm{i}}-\mu_{\mathrm{i}} \text { e } \mathrm{k}=1, \ldots \mathrm{p} .
\end{aligned}
$$

The expression of the covariance matrix $\mathrm{V}_{\mathrm{i}}$ was given by expression (3).

$$
\mathrm{V}_{\mathrm{i}}=\frac{\mathrm{A}_{\mathrm{i}}^{1 / 2} \mathrm{R}_{\mathrm{i}(\alpha)} \mathrm{A}_{\mathrm{i}}^{1 / 2}}{\phi}
$$

where $A_{i}$ is a diagonal matrix of the order mi $\times$ mi representing the total number of observations in the i-th package, $\varnothing$ is the dispersion parameter estimated by Pearson residuals, and $\operatorname{Ri}(\alpha)$ is the working correlation matrix, fixed by the autoregressive structure of order 1, which was specified by estimates of parameter vector $\alpha$, common to all packages with observations repeated over time. Thus, this structure was described in expression (4).

$$
R_{\mathrm{i}(\alpha)}=\left[\begin{array}{cccc}
1 & \hat{\alpha} & \cdots & \hat{\alpha}^{t} \\
\hat{\alpha} & 1 & \cdots & \hat{\alpha}^{t-1} \\
\vdots & \vdots & \ddots & \vdots \\
\hat{\alpha}^{t} & \cdots & \cdots & 1
\end{array}\right]
$$

The estimate of $\hat{\alpha}$ is given using the procedure specific to the AR (1) structure, as suggested by Liang and Zeger (1986). Thus, the temporal correlation of the response variable $y_{i j}$, indicating the $\mathrm{i}$-th package in $\mathrm{j}$-th time, with the response obtained at the later time $\mathrm{y}_{\mathrm{i}, \mathrm{j}+\mathrm{t}}$ for $\mathrm{t}=0,2 \ldots$ was incorporated into the model, providing the adjusted means plotted according to time.

The comparison between models was given by the significance of the parameter estimates, emphasizing the interactions of the packages with the temporal effect. In this context, non-significant interactions demonstrate a low contribution to the predictive power. Based to this criterion, the models were compared for the studied variables regarding the storage conducted in Brazil and the United States. 


\section{RESULTS AND DISCUSSION}

\subsection{Descriptive results}

The purpose of the results regarding relative humidity was not described in the predictions; therefore, we proceeded with the descriptive analysis using the values of maximum, minimum, and mean temperature (Figure 1). Values of maximum, minimum, and mean relative humidity (Figure 1) of the storage environment are shown for the period from October 2014 to March 2016 (Armazém Internacional in Poços de Caldas, MG, Brazil) and from October 2014 to December 2015 (warehouse of Café Imports company in Minneapolis, MN, United States).

The mean $\left(21^{\circ} \mathrm{C}\right)$, mean of maximum $(25$ $\left.{ }^{\circ} \mathrm{C}\right)$ and mean of minimum $\left(17^{\circ} \mathrm{C}\right)$ temperatures are presented in Figure 1a. The mean storage temperature conditions were considered good for maintaining coffee quality (ABREU, et al., 2017; ABREU et al., 2018), considering that the maximum values did not exceed $30{ }^{\circ} \mathrm{C}$ and the mean values were approximately $20{ }^{\circ} \mathrm{C}$, with periods of low temperatures of approximately 5 ${ }^{\circ} \mathrm{C}$ during winter.

The temperature outside the packages and inside the container reached values below $5{ }^{\circ} \mathrm{C}$ between March and April at the time of export (Figure 1b). These values have both positive and negative influences. The positive influence is the better conservation of coffee at low temperatures (ABREU, et al., 2017; ABREU et al., 2018). However, the temperature outside the impermeable packages can reach the dew point, causing water vapor condensation inside them. After arrival at the United States in May, the coffee was transported to the Café Imports warehouse. This warehouse has a controlled environment with mean temperature of $20^{\circ} \mathrm{C}$ (Figure $1 \mathrm{~b}$ ). The mean temperature in the period studied was $20^{\circ} \mathrm{C}$; the mean of maximum temperatures was $24^{\circ} \mathrm{C}$, while the mean of minimum temperatures was $17^{\circ} \mathrm{C}$, which represented favorable conditions for the maintenance of coffee quality.

The relative humidity averages of the external storage environment for both phases are shown in Figure 1. The maximum values of RH reached $80 \%$, with average of $60 \%$ throughout the period (Figure 1c). After export, the relative humidity of the environment outside the packages ranged from $33 \%$ to $84 \%$ (Figure 1d).

Coffee beans are hygroscopic and therefore change moisture with the environment. Green coffee beans in equilibrium with higher relative humidity, such as those observed in storage in Brazil (Figure 1c), can reach the equilibrium up to $13.5 \%$ of moisture content when in permeable packaging (BORÉM et al., 2008). Values above $11.5 \%$ of moisture are not recommended for storage and may lead to rapid grain bleaching. On the other hand, when coffee is stored in environments with low relative humidity 56\% (Figure 1d), the opposite process occurs, i.e. drying of beans stored in water vapor permeable packages. This phenomenon does not occur in impermeable packaging, what represents a great advantage for the storage of specialty coffees.
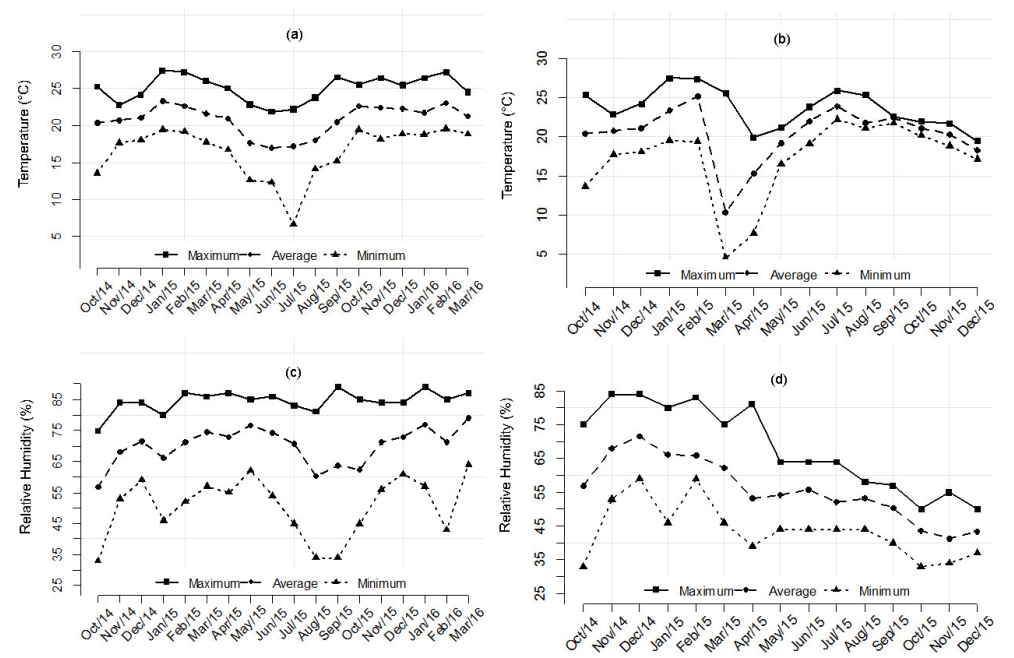

FIGURE 1 - Temperature of the outside environment for the Brazilian phase (a) and export phase (b) and Relative humidity (RH) of the outside environment of Brazilian phase (c) and export phase (d). 


\section{Results obtained by the adjustment of the GEE model}

Carbon dioxide can be passively concentrated from the respiration of beans or can be injected, actively modifying the atmosphere within the package. Carbon dioxide concentrations inside the packages above the normal values of atmospheric air $(0.03 \%)$ indicate that the package is impermeable to $\mathrm{CO}_{2}$ exchanges with the environment. Higher concentration of this gas within the packages allows reducing the respiratory rate, thus favoring a better conservation of coffee quality due to lower consumption of coffee reserves and also avoiding the formation of off-flavor from degradation of macro-molecules (Figure 2).

Results regarding the significance of the model parameter estimates are described in Table 2 . The interaction with time for all packages was significant ( $p$-value $<0.05$ ), except for the NCA package; the significance probability was superior to the level of significance, fixed on 0.05 , regarding $\mathrm{CO}_{2}$ concentration observed in the Brazil and United States storage.

There is statistical evidence to support that the significant effects have an important contribution to the predictive power of the proposed model. The highest $\mathrm{CO}_{2}$ concentrations were found in the CO treatment, in which $10 \%$ of $\mathrm{CO}_{2}$ was injected at the beginning of storage. The initial concentration decreased to levels near 5\% after 12 months of storage in Brazil (Figure 2a). Posteriorly, the $\mathrm{CO}_{2}$ concentration increased, reaching approximately $7 \%$ at 18 months of storage. In the export phase, the initial concentration decreased to levels near $4 \%$ after six months of storage (Figure 2b) and then increased up to $6 \%$ at 12 months of storage. The reduction in $\mathrm{CO}_{2}$ concentration in the first months is related to the ability of coffee to absorb and retain these gas molecules (BORÉM et al., 2013).

The increase in carbon dioxide concentration, in both phases, for treatments without $\mathrm{CO}_{2}$ injections in packages described by the suppliers Klabin and Videplast as having a high barrier to gas exchange results from the respiration of beans and the level of impermeability of the packaging to gas exchange. The high barrier paper (HBP), antifog (AF) and vacuum (V) packages concentrated more $\mathrm{CO}_{2}$ than the paper $(\mathrm{P})$, low barrier (LB), high barrier (HB), and jute (J) packages in which the $\mathrm{CO}_{2}$ level was constant and equal to the normal condition of atmospheric air (Figure 2a and 2b). The HB treatment presented lower $\mathrm{CO}_{2}$ concentration when compared to other high barrier treatments, both for the Brazilian and export phases. In the Brazilian phase, at 18 months, the HBP treatment presented higher $\mathrm{CO}_{2}$ concentration than the other treatments with a passive artificial atmosphere, i.e., without $\mathrm{CO}_{2}$ injections (Figure 2a).

Storage conditions and packaging type may allow changes in water content, respiration rate and reduce product quality during storage as a result of changes in the chemical composition of green coffee beans (BORÉM et al., 2013; NOBRE et al., 2007; RENDON; SALVA; BRAGAGNOLO, 2014; RIBEIRO et al., 2011; RIGUEIRA et al., 2009). Beans in packages without barrier ( $P$ and $J)$ and with LB increased the water content along the 18 months of storage in the Brazilian phase (Figure 3a).
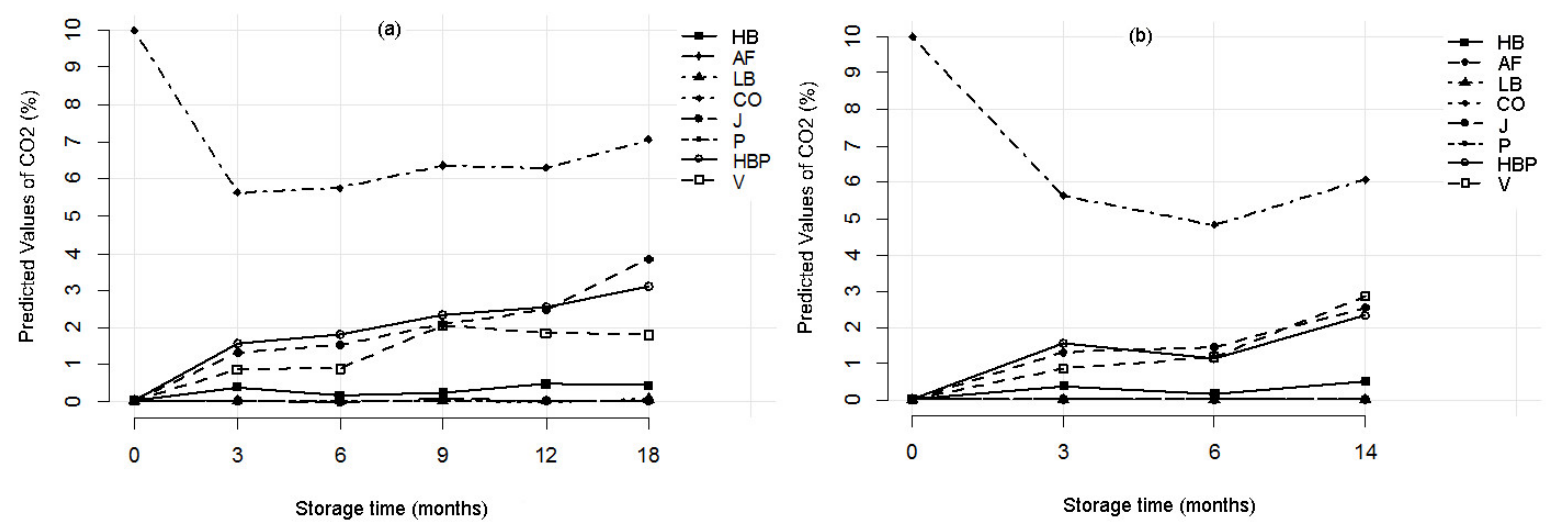

FIGURE 2 - Concentration of $\mathrm{CO}_{2}$ inside packages containing natural coffee in the Brazilian (a) and export phase (b); (P- Paper; LB - Paper + low barrier; HBP - Paper + high barrier; CO - Paper + high barrier + antifog $+\mathrm{CO}_{2}$; HB - High barrier plastic; AF -Paper + high barrier + antifog; V - Vacuum and J - Jute). 
TABLE 2 - Estimates of the GEE model considering the main effects of packages and the interaction with storage time for $\mathrm{CO}_{2}$ concentrations.

\begin{tabular}{ccccccc}
\hline & \multicolumn{3}{c}{ Storage phase in Brazil } & \multicolumn{3}{c}{ Export phase } \\
\hline Parameters & Estimates & Std_error & p-value & Estimates & Std_error & p-value \\
\hline NAB & 0.1492 & 0.0962 & 0.1208 & 0.1083 & 0.0997 & 0.2771 \\
NAF & 0.3116 & 0.1918 & 0.1043 & 0.4246 & 0.2748 & 0.1223 \\
NBB & 0.0288 & 0.0088 & 0.0011 & 0.0303 & 0.0006 & 0.0000 \\
NCO & 7.5959 & 1.3277 & 0.0000 & 7.7875 & 1.4451 & 0.0000 \\
NJ & 0.0510 & 0.0189 & 0.0069 & 0.0392 & 0.0060 & 0.0000 \\
NP & 0.0298 & 0.0018 & 0.0000 & 0.0301 & 0.0002 & 0.0000 \\
NPAB & 0.5864 & 0.3220 & 0.0686 & 0.4955 & 0.3787 & 0.1907 \\
NV & 0.4762 & 0.2591 & 0.0661 & 0.0886 & 0.0806 & 0.2716 \\
Time & 0.0151 & 0.0068 & 0.0270 & 0.0281 & 0.0069 & 0.0000 \\
NAF: Time & 0.1905 & 0.0076 & 0.0000 & 0.1304 & 0.0214 & 0.0000 \\
NBB: Time & -0.0164 & 0.0073 & 0.0236 & -0.0296 & 0.0069 & 0.0000 \\
NCO: Time & -0.1055 & 0.1176 & 0.3696 & -0.2246 & 0.1520 & 0.1396 \\
NJ: Time & -0.0213 & 0.0063 & 0.0006 & -0.0283 & 0.0065 & 0.0000 \\
NP: Time & -0.0154 & 0.0069 & 0.0253 & -0.0285 & 0.0069 & 0.0000 \\
NPAB: Time & 0.1549 & 0.0213 & 0.0000 & 0.1083 & 0.0252 & 0.0000 \\
NV: Time & 0.0787 & 0.0276 & 0.0043 & 0.1718 & 0.0014 & 0.0000 \\
\hline
\end{tabular}
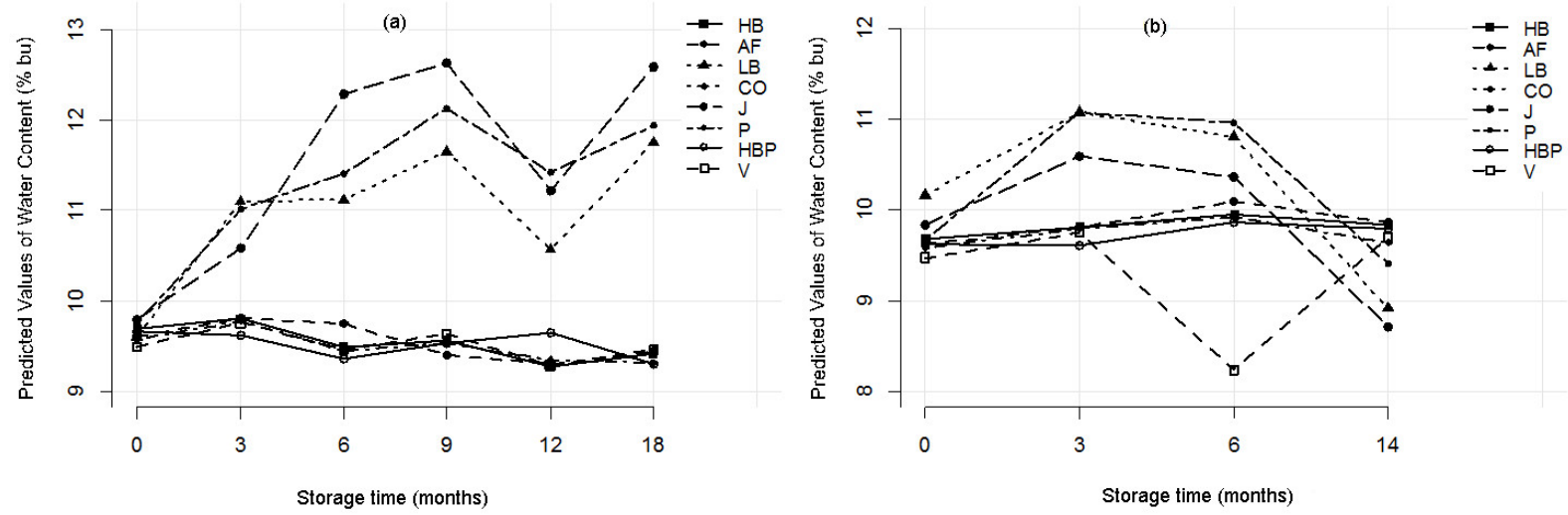

FIGURE 3 - Water content of the natural coffee in different packages over 18 months (a) and 14 months (b) of storage; (P- Paper; LB - Paper + low barrier; HBP - Paper + high barrier; CO - Paper + high barrier + antifog + $\mathrm{CO}_{2} ; \mathrm{HB}$ - High barrier plastic; AF -Paper + high barrier + antifog; V - Vacuum and J - Jute).

For the export phase, these same packages exhibited variation in water content throughout the storage period in response to variations in the relative humidity during export activities and in the equilibrium stage upon storage in the United States (Figure 3b). For the other packages, the water content remained stable, indicating the effectiveness of the studied packages as a barrier for water vapor (Figure $3 a$ and $3 b$ ). The hygroscopic equilibrium under warehouse conditions in Minneapolis caused the water content of the coffee in permeable packages to decline to values below 10\% (wb) (Figure 3b). 
The results described in Table 3 demonstrate discordance between the effects of packaging and storage time on water content for beans stored in Brazil and the United States. These results do not invalidate the recommendations for using the packages, but the nonsignificant effects of the predictions ( $\mathrm{p}$-value $<0.05$ ) resulted in a low contribution to the proposed model.

The estimates of parameters for the sensorial analysis are presented in Table 4 . The common nonsignificant effects observed in Brazil and the United States regarding the time interactions of NCO and NPAB packages demonstrate a low contribution to the prediction power of the proposed models.

Results of the sensory analysis of natural coffee are shown in Figure 4.

According to the SCA methodology used for the sensory evaluation of coffee, samples with scores from 85 to 89 are classified as excellent, while those with scores from 80 to 84 are classified as very good, although these are all considered specialty coffee. Although they may present good quality, coffee samples with scores lower than 80 are not classified as specialty coffee (SCAA, 2015).
Coffee in all the packages decreased in score along the storage phase in Brazil. During the first three months of storage, there were no differences and all packages maintained coffee at scores higher than 80 points (Figure $4 a$ ).

From the sixth month on, the packages without barrier ( $\mathrm{J}$ and $\mathrm{P}$ ) and with LB were below this level and therefore were no longer classified as specialty coffees. After 18 months of storage, only the coffee in $\mathrm{V}, \mathrm{CO}$, and HBP packages were classified as specialty coffees. These results support the hypothesis that it is possible to keep coffee classified as a specialty (score above 80 ) for long periods of storage. For the export phase, green coffee beans stored in packages without barrier (P and $\mathrm{J}$ ) and with low barrier (LB) presented greater reductions in sensory quality at the end of 14 months of storage (Figure $4 \mathrm{~b}$ ), reaching scores lower than 80 points.

The present work presents additional contributions to previous studies (ABREU et al., 2015; BORÉM et al., 2013, 2008; CORADI; BORÉM, 2009; ISMAIL; ANUAR; SHAMSUDIN, 2013; NOBRE et al., 2007; RIBEIRO et al., 2011) as the quality of specialty coffee was evaluated both in the storage time in the origin and after transport and storage in the importing country.

TABLE 3 - Estimates of the GEE model considering the main effects of packages and interaction with storage time for the variable water content.

\begin{tabular}{ccccccc}
\hline & \multicolumn{3}{c}{ Brazil } & & United States \\
\hline Fonte & Estimates & Std_error & $\operatorname{Pr}(<|\mathrm{W}|)$ & Estimates & Std_error & $\operatorname{Pr}(<|\mathrm{W}|)$ \\
\hline NAB & 9.7244 & 0.0513 & 0.0000 & 9.7984 & 0.0802 & 0.0000 \\
NAF & 9.6248 & 0.1031 & 0.0000 & 9.6937 & 0.0781 & 0.0000 \\
NBB & 10.3943 & 0.4593 & 0.0000 & 10.7484 & 0.5683 & 0.0000 \\
NCO & 9.6152 & 0.0861 & 0.0000 & 9.6698 & 0.0666 & 0.0000 \\
NJ & 10.4834 & 0.4889 & 0.0000 & 10.3248 & 0.4017 & 0.0000 \\
NP & 10.4534 & 0.3130 & 0.0000 & 10.6228 & 0.4722 & 0.0000 \\
NPAB & 9.6818 & 0.1132 & 0.0000 & 9.7525 & 0.0308 & 0.0000 \\
NV & 9.7152 & 0.0877 & 0.0000 & 9.4659 & 0.1936 & 0.0000 \\
Time & -0.0275 & 0.0094 & 0.0033 & 0.0084 & 0.0085 & 0.3232 \\
NAF: Time & 0.0110 & 0.0049 & 0.0248 & 0.0077 & 0.0039 & 0.0499 \\
NBB: Time & 0.1059 & 0.0353 & 0.0027 & -0.0987 & 0.0494 & 0.0457 \\
NCO: Time & 0.0095 & 0.0032 & 0.0034 & -0.0056 & 0.0050 & 0.2587 \\
NJ: Time & 0.1557 & 0.0413 & 0.0002 & -0.1043 & 0.0326 & 0.0014 \\
NP: Time & 0.1221 & 0.0301 & 0.0001 & -0.0764 & 0.0423 & 0.0710 \\
NPAB: Time & 0.0213 & 0.0279 & 0.4456 & -0.0128 & 0.0051 & 0.0130 \\
NV: Time & 0.0078 & 0.0109 & 0.4727 & -0.0057 & 0.0246 & 0.8176 \\
\hline
\end{tabular}


TABLE 4 - Estimates of the GEE model considering the main effects of the packages and interaction with time of storage for the sensorial analysis variable.

\begin{tabular}{ccccccc}
\hline & \multicolumn{3}{c}{ Brazil } & & United States \\
\hline Parameters & Estimates & Std_error & p-value & Estimates & Std_error & p-value \\
\hline NAB & 84.7510 & 0.6225 & 0.0000 & 85.0647 & 0.4617 & 0.0000 \\
NAF & 85.4700 & 0.5376 & 0.0000 & 85.3322 & 0.3713 & 0.0000 \\
NBB & 84.4119 & 1.8433 & 0.0000 & 86.3577 & 0.8389 & 0.0000 \\
NCO & 83.5020 & 1.4284 & 0.0000 & 84.5888 & 0.8584 & 0.0000 \\
NJ & 85.0117 & 1.1776 & 0.0000 & 84.9464 & 1.1300 & 0.0000 \\
NP & 84.1250 & 0.8611 & 0.0000 & 85.0819 & 0.4350 & 0.0000 \\
NPAB & 83.8668 & 1.9255 & 0.0000 & 85.1125 & 1.4317 & 0.0000 \\
NV & 86.3796 & 0.6676 & 0.0000 & 85.2690 & 1.3412 & 0.0000 \\
Time & -0.2100 & 0.0480 & 0.0000 & -0.2020 & 0.0353 & 0.0000 \\
NAF: Time & -0.1369 & 0.0498 & 0.0059 & -0.1992 & 0.0454 & 0.0000 \\
NBB: Time & -0.3470 & 0.1157 & 0.0027 & -0.8141 & 0.0496 & 0.0000 \\
NCO: Time & 0.1369 & 0.0906 & 0.1308 & -0.1127 & 0.0637 & 0.0771 \\
NJ: Time & -0.5659 & 0.0561 & 0.0000 & -0.3396 & 0.0898 & 0.0002 \\
NP: Time & -0.3410 & 0.0569 & 0.0000 & -0.5191 & 0.0459 & 0.0000 \\
NPAB: Time & 0.0713 & 0.1234 & 0.5636 & -0.1064 & 0.1099 & 0.3333 \\
NV: Time & -0.1220 & 0.0237 & 0.0000 & 0.0388 & 0.1320 & 0.7688 \\
\hline
\end{tabular}
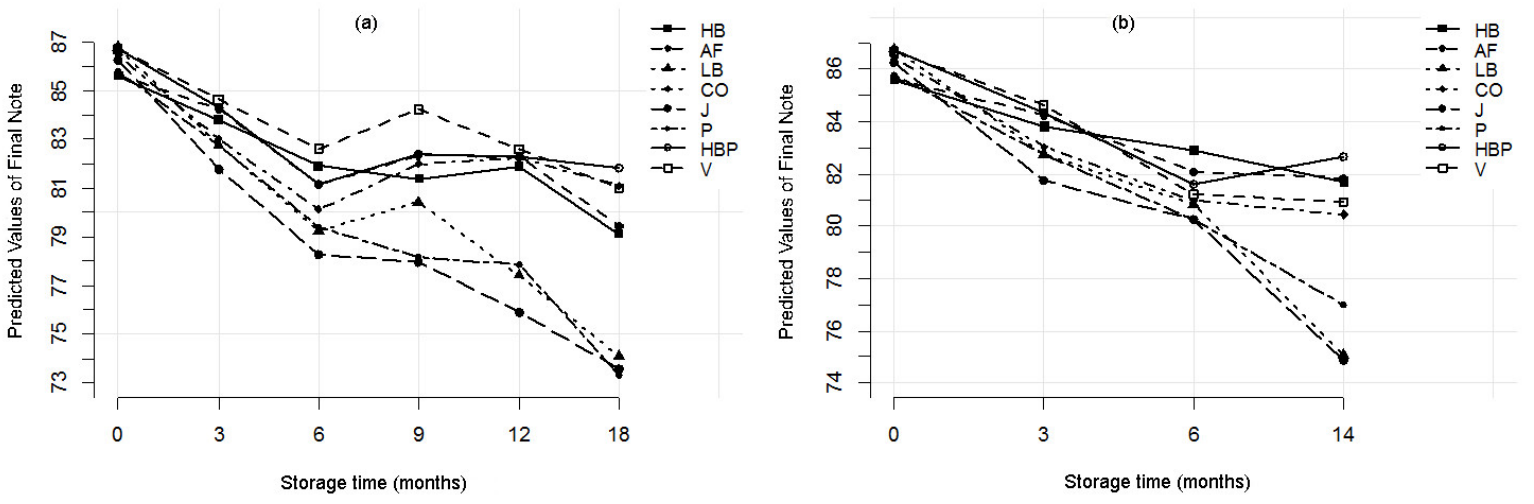

FIGURE 4 - Sensory analysis of natural coffee over 18 months (a) and 14 months (b) of storage; (P- Paper; LB - Paper + low barrier; HBP - Paper + high barrier; $\mathrm{CO}$ - Paper + high barrier + antifog $+\mathrm{CO}_{2}$; HB - High barrier plastic; AF -Paper + high barrier + antifog; V - Vacuum and J - Jute).

Many coffee importers are still resistant to the use of hermetic bags, maintaining the traditional use of jute bags. The results of this study emphasize that this type of bag or other kind of packages permeable to oxygen are not recommended for storing and exporting specialty coffees.
In contrast, green beans stored in highbarrier packages remained in the specialty category and presented behavior similar to beans in vacuum packing. This indicates that technologies of high barrier packaging for green coffee beans are recommended for storage and export of specialty 
coffee, which offer the same protection as vacuum packing.

The sucrose concentration was relatively stable for coffee beans in HBP and vacuum packing stored in Brazil, thus confirming the similar capacity of high-barrier packages in preserving coffee quality when compared to the vacuum ones (Figure 5a). The absence of a barrier to gases and water vapor favors rewetting of coffee beans. Consequently, it leads to the increase of respiration process. As glucose molecule from sucrose hydrolysis is the main source of energy in respiration, a decrease in sucrose concentration was observed during storage of coffee in paper packaging $(\mathrm{P})$. As respiration increases and sucrose content reduces, the loss of sensory quality was also observed.
The main effects and interactions of parameter estimates obtained in Brazil and the United States were significant ( $\mathrm{p}$-value $<0.05$ ), as described in Table 5. The results were similar for the export phase, in which the sucrose concentration of green coffee beans in all packages reduced with increased time of storage (Figure $5 b$ ). After 14 months, the natural coffee in packages without barrier $(\mathrm{P})$ presented greater reduction in sucrose concentrations, indicating a higher deterioration of beans in this type of package, as observed in sensory analysis. In this process, sucrose hydrolysis releases the monosaccharides glucose and fructose, which become readily available for respiration. This result confirms other indicators of changes in coffee quality, such as sensory analysis.
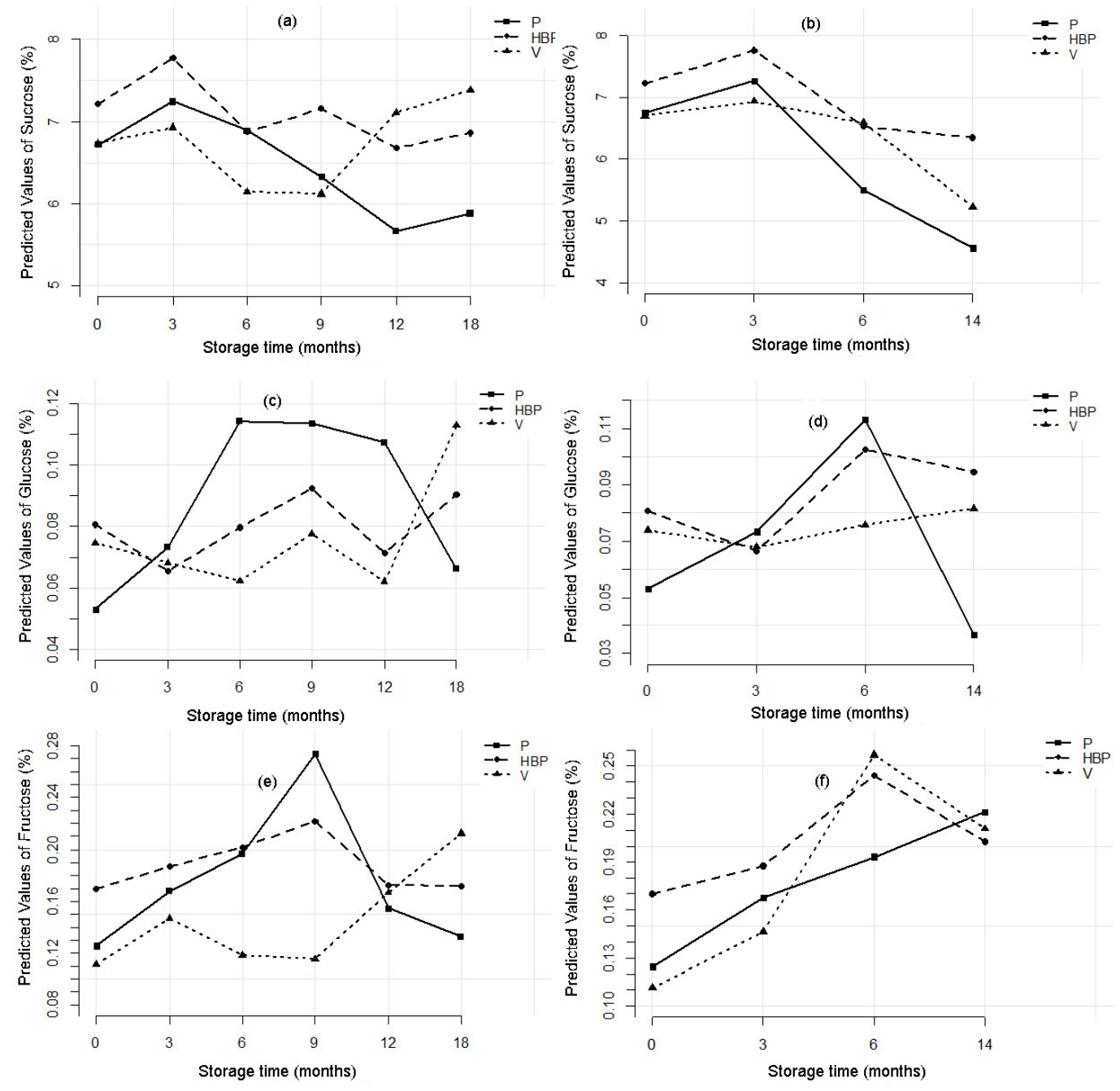

FIGURE 5 - Sucrose (a, b), glucose (c, d) and fructose (e, f) concentration for natural coffee along 18 months and 14 months of storage, respectively; (P- Paper; HBP - Paper + high barrier and V - Vacuum). 
The glucose and fructose concentrations presented similar behavior among the types of packaging, which increased in packages without barriers (J) up to 9 months of storage, followed by a reduction up to 18 months of storage (Figure 5c and $5 \mathrm{e}$ ). This result is consistent with the behavior of sucrose concentrations, which reduced with increased time of storage because these sugars were degraded, then increasing the ratio of glucose and fructose to total sugars up to 9 months of storage. After this period, these sugars contents decreased dramatically, indicating their consumption by the beans because sugars of low molecular weight (glucose and fructose) are preferably consumed in respiration (BYTOF, 2019).

Both in Brazil and United States the models of temporal effects and interactions with the packages were nonsignificant, as described in Table 5. Therefore, there is evidence that all model parameters contributed similarly on predicting the recommendations of the evaluated packages.
The prediction power of models was distinct for the analysis of fructose content, which presented nonsignificant results (Table 5) for the temporal interactions. These models were distinct from the models proposed to evaluate the content of fructose observed in the storage conducted in Brazil and the USA.

The glucose and fructose concentrations for natural coffee in HBP were stable throughout storage in Brazil. Nevertheless, the fructose and glucose percentages of vacuum-packed coffee almost doubled throughout the 18 months of storage. A probable explanation for this phenomenon is that even under ideal conditions, beans breathe (BORÉM et al., 2013; RIBEIRO et al., 2011), as suggested in this study by the reduction in the sucrose concentration throughout the storage period. However, high-barrier packaging allowed beans to be protected for a longer period, impeding them from consuming the low molecular weight sugars, as in jute $(\mathrm{J})$ after nine months of storage.

TABLE 5 - Estimates of the GEE model considering the main effects of packages and interaction with time of storage for the sucrose, glucose and fructose content variables.

\begin{tabular}{|c|c|c|c|c|c|c|c|}
\hline & \multirow[b]{2}{*}{ Parameters } & \multicolumn{3}{|c|}{ Brazil } & \multicolumn{3}{|c|}{ United States } \\
\hline & & Estimates & Std_error & p-value & Estimates & Std error & p-value \\
\hline \multirow{6}{*}{ 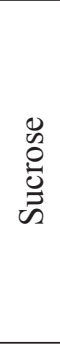 } & NP & 7.0821 & 0.2347 & 0.0000 & 7.4137 & 0.3865 & 0.0000 \\
\hline & NPAB & 7.3983 & 0.2031 & 0.0000 & 7.4662 & 0.1925 & 0.0000 \\
\hline & NV & 6.4392 & 0.2474 & 0.0000 & 6.7337 & 0.3123 & 0.0000 \\
\hline & Time & -0.0776 & 0.0206 & 0.0002 & -0.2056 & 0.0263 & 0.0000 \\
\hline & NPAB: Time & 0.0395 & 0.0092 & 0.0000 & 0.1112 & 0.0195 & 0.0000 \\
\hline & NV: Time & 0.1149 & 0.0285 & 0.0001 & 0.1164 & 0.0304 & 0.0001 \\
\hline \multirow{6}{*}{$\begin{array}{l}\mathscr{U} \\
0 \\
0 \\
0 \\
0\end{array}$} & NP & 0.0795 & 0.0165 & 0.0000 & 0.0752 & 0.0154 & 0.0000 \\
\hline & NPAB & 0.0745 & 0.0046 & 0.0000 & 0.0824 & 0.0061 & 0.0000 \\
\hline & NV & 0.0605 & 0.0058 & 0.0000 & 0.0680 & 0.0017 & 0.0000 \\
\hline & Time & 0.0010 & 0.0018 & 0.5753 & -0.0017 & 0.0017 & 0.2975 \\
\hline & NPAB: Time & -0.0003 & 0.0022 & 0.8805 & 0.0027 & 0.0015 & 0.0655 \\
\hline & NV: Time & 0.0009 & 0.0027 & 0.7529 & 0.0030 & 0.0015 & 0.0535 \\
\hline \multirow{6}{*}{ 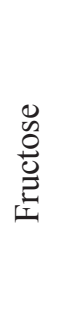 } & NP & 0.1716 & 0.0306 & 0.0000 & 0.1174 & 0.0092 & 0.0000 \\
\hline & NPAB & 0.1924 & 0.0111 & 0.0000 & 0.2011 & 0.0192 & 0.0000 \\
\hline & NV & 0.1081 & 0.0111 & 0.0000 & 0.1492 & 0.0250 & 0.0000 \\
\hline & Time & 0.0002 & 0.0030 & 0.9544 & 0.0089 & 0.0010 & 0.0000 \\
\hline & NPAB: Time & -0.0007 & 0.0020 & 0.7472 & -0.0083 & 0.0010 & 0.0000 \\
\hline & NV: Time & 0.0046 & 0.0038 & 0.2218 & -0.0017 & 0.0018 & 0.3502 \\
\hline
\end{tabular}


The vacuum (V) packing ensured the better maintenance of glucose concentrations throughout storage of the exported beans. Glucose concentrations in HBP packages increased subtly throughout storage. However, beans in jute $(\mathrm{J})$ bags exhibited a rapid increase in the concentration of this sugar, followed by a drastic decline, thus indicating a rapid hydrolysis of sucrose into glucose, followed by nearly complete consumption of such glucose.

The fructose concentrations of coffee beans in the three types of packages increased during storage. These results are consistent with the sucrose percentage that decreased throughout storage in the three types of packages because it was hydrolyzed to sugars of low molecular weight (glucose and fructose) (Figure 5d and 5f).

\section{CONCLUSIONS}

Specialty coffee beans stored in permeable packaging (jute or paper) in warehouse with similar environment to the Brazilian summer lose their initial sensory classification at six months of storage.

High-barrier packages have the same ability to maintain the quality of specialty coffees at 18 months storage compared to vacuum packages.

The export of specialty coffees should take place in high-barrier or vacuum packaging.

High-barrier packaging maintains the quality of coffee after export for up to 10 months of storage in the final country of destination.

\section{ACKNOWLEDGMENTS}

The authors would like to thank the Conselho Nacional de Desenvolvimento Científico e Tecnológico (CNPq), the Fundação de Amparo à Pesquisa do Estado de Minas Gerais (Fapemig), the Coordenação de Aperfeiçoamento de Pessoal de Nível Superior (Capes), the Instituto Nacional de Ciência e Tecnologia do Café (INCTCafé).

Funding: This work was supported by the Brazil Specialty Coffee Association (BSCA), the Agência Brasileira de Promoção de Exportações e Investimentos (APEX-Brasil), the Videplast Industria de Embalagens Ltda, the Klabin SA, the Carmo Coffes, and the Bourbon Specialty Coffee.

\section{REFERENCES}

ABREU, G. F. et al. Alterações na coloração de grãos de café em função das operações pós-colheita. Coffee Science, Lavras, v. 10, n. 4, p. 429-436, 2015.
ABREU, G. F. et al. Simultaneous optimization of coffee quality variables during storage. Revista Brasileira de Engenharia Agrícola e Ambiental, Campina Grande, v. 21, n. 1, p. 56-60, 2017.

ABREU, G. F. et al. Antioxidant enzymes preserving coffee quality in refrigerateenvironment. Biotecnologia Vegetal, v. 18, n. 3, p. 151-159, 2018.

ALVES, G. E. et al. Physiological and sensorial quality of Arabica coffee subjected to different temperatures and drying airflows. Acta Scientiarum Agronomy, Maringá, v. 39, n. 2, p. 225, 2017.

ASSOCIAÇÃO BRASILEIRA DE CAFÉS ESPECIAIS. Café especial: produção no Brasil deve ultrapassar Colômbia em menos de dois anos. Disponível em: $<\mathrm{http}: / /$ siteantigo.bsca.com.br/noticia. php?id=453\%3E $>$. Acesso em: 15 ago. 2017.

ASTM D3985-05. American Society for Testing and Materials. Standard test methods for oxygen gas transmission rate through plastic film and sheeting using a coulometric sensor, 2005.

ASTM F1249 - 13. AMERICAN SOCIETY FOR TESTING AND MATERIALS. Standard Test Method for Water Vapor Transmission Rate Through Plastic Film and Sheeting Using a Modulated Infrared Sensor, 2013.

BORÉM, F. M. et al. Avaliação sensorial do café cereja descascado, armazenado sob atmosfera artificial e convencional. Ciencia e Agrotecnologia, Lavras, v. 32, n. 6, p. 1724-1729, 2008.

BORÉM, F. M. et al. Evaluation of the sensory and color quality of coffee beans stored in hermetic packaging. Journal of Stored Products Research, Oxford, v. 52, p. 1-6, 2013.

BYTOF, G. Flavor development during postharvest treatment of coffee - A Holistic Approach. In: HII, C. L.; BOREM, F. M. Drying and Roasting of Cocoa and Coffee, Boca Raton, CRC Press, 2019, p. 171234.

CORADI, P.; BORÉM, F. M. Alterações dos parâmetros físico químicos na qualidade de bebida do café natural e despolpado em função de diferentes tipos de secagem e condição de armazenamento. Revista Brasileira de Armazenamento, Viçosa, n. 11, p. 54-63, 2009. 
INTERNATIONAL ORGANIZATION FOR STANDARDIZATION. Green coffee - determination of loss in mass at $105{ }^{\circ} \mathrm{C}$. Disponível em: <https:// www.iso.org/standard/38375.html>.

ISMAIL, I.; ANUAR, M. S.; SHAMSUDIN, R. Effect on the physico-chemical properties of liberica green coffee beans under ambient storage. International Food Research Journal, Serdang, v. 20, n. 1, p. 255264, 2013.

LIANG, K.-Y.; ZEGER, S. L. Longitudinal data analysis using generalized linear Models. Biometrika, v. 73, n. 1, p. 13-22, 1986.

LINGLE, T. The coffee cupper' s handbook. 4th. ed. Long Beach: Specialty Coffee Association of America, 2011.

NOBRE, G. W. et al. Alteraçoes Químicas do caféCereja Desecado Durante o Armazenamento. Coffee Science, Lavras, v. 2, n. 1, p. 1-9, 2007.

RENDÓN, M. Y.; SALVA, T. de J. G.; BRAGAGNOLO, $\mathrm{N}$. Impact of chemical changes on the sensory characteristics of coffee beans during storage. Food Chemistry, London, v. 147, p. 279-286, Mar. 2014.
RIBEIRO, F. C. et al. Storage of green coffee in hermetic packaging injected with $\mathrm{CO} 2$. Journal of Stored Products Research, Oxford, v. 47, n. 4, p. 341-348, out. 2011.

RIBEIRO, D. E. et al. Interaction of genotype, environment and processing in the chemicalcomposition expression and sensorial quality of Arabica coffee. African Journal ofAgricultural Research, v. 11, n. 27, p. 2412-2422, July 2016.

RIGUEIRA, R. J. A. et al. Armazenamento de Grãos de Café Cereja Descascado em Ambiente Refrigerado. Engenharia na Agricultura, Viçosa, v. 17, n. 4, p. 323-333, 2009.

SAATH, R. et al. Alterações na composição química e sensorial de café (Coffea arabica L.) nos processos pós colheita. Energia na Agricultura, Botucatu, v. 27, n. 2, p. 96-112, 2012.

SCAA - Specialty Coffee Association of America. SCAA Protocols - Cupping Specialty Coffee. SCAA, Santa Ana, 2015, 10 p.

TAVEIRA, J. H. S. et al. Perfis proteicos e desempenho fisiológico de sementes de café submetidas a diferentes métodos de processamento e secagem. Pesquisa Agropecuaria Brasileira, Brasília, v. 47, n. 10, p. 1511-1517, 2012. 